MIDAS

Museus e estudos interdisciplinares

9| 2018

Varia

\title{
Antos, Zvjezdana, Annette B. Fromm e Viv Golding, eds. - Museums and Innovations
}

Ana Carvalho

\section{OpenEdition}

Journals

Edição electrónica

URL: http://journals.openedition.org/midas/1333

DOI: $10.4000 /$ midas.1333

ISSN: 2182-9543

Editora:

Alice Semedo, Paulo Simões Rodrigues, Pedro Casaleiro, Raquel Henriques da Silva, Ana Carvalho

Refêrencia eletrónica

Ana Carvalho, "Antos, Zvjezdana, Annette B. Fromm e Viv Golding, eds. - Museums and Innovations », MIDAS [Online], 9 | 2018, posto online no dia 25 janeiro 2018, consultado no dia 24 setembro 2020. URL : http://journals.openedition.org/midas/1333; DOI : https://doi.org/10.4000/midas.1333

Este documento foi criado de forma automática no dia 24 setembro 2020.

\section{(c) (i) (2) (-)}

Midas is licensed under a Creative Commons Attribution-NonCommercial-ShareAlike 3.0 International License 


\title{
Antos, Zvjezdana, Annette B. Fromm e Viv Golding, eds. - Museums and Innovations
}

\author{
Ana Carvalho
}

\section{REFERÊNCIA}

Antos, Zvjezdana, Annette B. Fromm, e Viv Golding, eds. 2017. Museums and Innovations. Cambridge: Cambridge Scholars Publishing. 241 páginas, ISBN: 978-1-4438-1268-9.

Como é que os museus podem ter um impacto positivo na sociedade global? Que inovações se podem identificar actualmente em museus etnográficos e de história social $?^{1}$ Podem ou devem os museus ter um agenciamento provocador na sociedade, através de exposições e programas públicos que instiguem debates alargados que possam servir diferentes comunidades? É a partir deste enunciado que o livro propõe uma reflexão sobre as formas de pensar e trabalhar em museus, na perspectiva de encorajar práticas museológicas mais críticas e criativas, e contextos de trabalho colaborativos.

O livro tem por base uma selecção de comunicações apresentadas na conferência anual do ICME (Comité Internacional do ICOM para Museus e Colecções de Etnografia) com o mesmo título - Museums and Innovations, que decorreu em Zagreb (Croácia), entre $14 \mathrm{e}$ 16 de Outubro de 2014.

3 Para o livro contribuiu um total de 23 autores, entre investigadores, professores e profissionais de museus a actuar em diferentes frentes (da gestão, à documentação, à curadoria, entre outras), provenientes principalmente da área da história e da antropologia, incluindo da história da arte, com especializações em museologia e património. A diversidade da cobertura geográfica dos contributos é também digna de nota: Alemanha, Irlanda do Norte, Malta, Sérvia, Croácia, Itália, Espanha, Polónia, 
Finlândia, Estónia, Holanda, Rússia e Bélgica, contrariando lógicas que, porventura, estamos mais habituados a observar.

4 Um outro aspecto relevante é a diversidade de casos apresentados: museus de diferentes tutelas, tipologias e escalas, nomeadamente museus de universidade (ex. Universidade de Gante), museus de cidade (ex. Helsínquia, Amesterdão), museus de história, museus etnográficos, museus nacionais (ex. Estonian National Museum), museus de âmbito mais regional (ex. Valencian Museum of Ethnology) ou local (ex. Lucca Museum of the Risorgimento, Bir Mula Heritage Museum, Open Air Museum "Old Village"), experiências com exposições temporárias no espaço público (Berlim), projectos fora do contexto museal (ex. Belonging Project), incluindo análises museológicas mais panorâmicas (Moscovo, Berlim), para referir apenas alguns.

5 Participação, inovação e transformação são palavras-chave neste livro. Relevância é outra palavra usada em vários capítulos, corroborando a premência de articulação dos museus com a sociedade contemporânea. Aborda-se a complexidade das identidades, $o$ papel dos museus como agentes de influência nas comunidades e nos governos, e maior activismo na defesa da justiça social, ajudando a responder a necessidades e problemas societais. Outros referentes de análise incluem as histórias "difíceis" associadas ao colonialismo, e ainda o papel central da temática das migrações. Além disso, as colecções prevalecem como elementos-chave de novas abordagens e reinterpretações, mas também o compromisso de envolver os públicos já não apenas entendidos como passivos, mas com maior agenciamento.

O livro organiza-se em seis partes: 1) Explorando Identidade e Comunidade; 2) Comunicando Património e Intangibilidade; 3) Transformações; 4) Participação e Justiça Social; 5) Desenvolvendo Novas Práticas; e 6) Novas Vozes e (Re)Interpretação. Apesar da utilidade de organizar os conteúdos, por si só estes separadores são pouco operativos, uma vez que muitos dos capítulos se encaixariam em mais do que uma das secções enunciadas.

7 Longe de representarem práticas mainstream, muitos dos contributos incluídos no livro reafirmam e assentam em preocupações, como as que referimos acima, que parecem apontar para tendências que têm sido evidenciadas por via de um crescendo de literatura sobre museologia e museus. New Trends in Museology (2011), Nouvelles Tendances de la Muséologie (2016) são dois exemplos, entre outras obras, que perspectivam esses caminhos. A mais-valia deste livro reside na ancoragem em práticas que, com uma certa dose de experimentalismo, procuram testar e implementar alguns dos pressupostos referidos, seja por via de uma reflexão de iniciativa externa, seja pelos próprios intervenientes nestes processos. Muitos dos casos apresentados advêm também de processos de transformação induzidos pela renovação de exposições ou de reestruturações mais alargadas das próprias organizações museais. Dar nota das opções tomadas e dos princípios que guiaram estas mudanças pode ser, na nossa perspectiva, muito enriquecedor para melhor compreender as diferentes dinâmicas e ritmos que estimulam o complexo panorama museológico internacional.

8 Apesar de se notarem diferentes níveis de aprofundamento teórico e prático entre os 16 capítulos, no geral oferecem uma leitura cativante. Entre estes destacamos quatro capítulos por acentuarem aspectos que, em nosso entender (e assumindo desde logo a subjectividade implícita nesta escolha por conta do nosso próprio percurso), são significativos nas práticas museológicas contemporâneas. Isto é, a transformação da forma de trabalhar das organizações museais e dos profissionais de museus em prol de 
modelos hipoteticamente mais eficazes e que colocam em primeiro plano os visitantes e o seu envolvimento (ex. capítulo dez e 11); O Helsinki City Museum inaugurou uma nova sede em 2016. Este é também o pano de fundo em que Jari Harju, historiadora e conservadora deste museu, dá conta ao longo do capítulo dez (The Helsinki City Museum's New Exhibition Policy), explicando o racional e a metodologia seguida para elaborar uma nova política de exposições (2014-2018). Um dos métodos utilizados consistiu num inquérito interno envolvendo os profissionais do museu (aproximadamente 100 pessoas) de todas as áreas, na tentativa de construir uma visão partilhada e estratégica para o museu.

9 O capítulo 11 (Participation in the Museum: Diverse Audiences and their Motivations), da autoria de Agnes Aljas, investigadora do Estonian National Museum, centra-se numa reflexão sobre as mais de 30 iniciativas de base participativa promovidas desde 2007. A autora evidencia a diversidade de práticas participativas desenvolvidas - online e offline, destinadas a diferentes segmentos de público e a partir formatos distintos. 0 museu, fundado em 1909, abriu ao público em 2016 num novo edifício. Este reenquadramento permitiu repensar a relação do museu com os públicos, recorrendo às opiniões das pessoas e às suas experiências pessoais para moldar os programas públicos desenvolvidos. Neste exercício de análise, a autora explica porque algumas das iniciativas foram bem sucedidas e outras não. $O$ que merece realce nesta proposta de reflexão é a importância de escrutínio e avaliação que estes processos experimentais exigem no sentido de poder capitalizar a experiência adquirida de modo a ajustar práticas futuras. De uma maneira geral, apesar de as práticas participativas aplicadas em contexto museológico se identificarem como abordagens oportunas e relevantes, este é ainda um campo de difícil concretização pelas organizações no sentido de uma maior partilha de funções, poder e responsabilidades (p. 147).

O capítulo 12 (Media in Contemporary Heritage Presentation: The Case of the Amsterdam Museum) coloca a tónica na aplicação de soluções multimédia nas exposições e a problematização acerca da sua eficácia. Assinado por Elef Masson (professora assistente do departamento de Media Studies da Universidade de Amesterdão), este capítulo tem como objecto de análise a "nova" exposição permanente Amesterdam DNA (2011), na qual se recorre ao tridimensional para estabelecer uma narrativa sobre a história da cidade assente na projecção de sete filmes animados. A autora problematiza o uso do multimédia, questionando se esta utilização aportou relevância. Uma maior integração das tecnologias e do universo digital afirma-se actualmente como uma tendência no campo do património e do mundo dos museus. Os argumentos são conhecidos. Têm por base a ideia de que o universo digital e tecnológico está hoje muito mais entrosado na vida das pessoas, sobretudo dos mais jovens - os nativos digitais, que no seu quotidiano aplicam já novas formas de aceder à informação. Nesta perspectiva, a oportunidade reside em acompanhar estes fenómenos, conquistar os públicos mais jovens e, por outro lado, a não ficar para trás num contexto que é cada vez mais competitivo. Outros argumentos sustentam o seu contributo para ajudar a democratizar os museus ao descentrar a tónica da autoridade, tradicionalmente remetida aos especialistas, para os visitantes, criando espaço para interpretações alternativas e mais plurais de objectos e iniciativas, ou possibilitar contextos mais favoráveis para que sejam os visitantes a dirigir a sua própria aprendizagem (pp. 163-164). Apesar da benevolência deste quadro, a autora demonstra que nem sempre estes argumentos se aplicam na prática ou é evidente o modo como algumas soluções de suporte multimédia aportam contributos úteis ou relevantes no cômputo geral (p. 164). Um dos dados que a autora apresenta não 
deixa de surpreender. Apesar de se assistir a uma tendência para a substituição de textos de parede privilegiando apresentações multimédia interactivas, estas aplicações não tem reduzido a quantidade de informação disponibilizada ao visitante, tal como se esperaria, mas pelo contrário têm favorecido o seu aumento (p. 170). Da análise da exposição Amesterdam DNA, Masson conclui, entre outros aspectos, que as soluções multimédia trouxeram em alguns casos complicações acrescidas, em vez de levar mais longe a optimização destes recursos (p. 164). Ainda que as conclusões deste estudo de caso não possam ser extrapoladas para todas as exposições que recorrem a soluções multimédia, é relevante como lembrete de que o recurso ao universo digital e às tecnologias tem potencialidades, mas a sua aplicação não é linear, devendo implicar uma análise reflexiva caso a caso sobre os aportes específicos de cada ferramenta.

11 Destacamos, ainda, o capítulo seis (Engaging with Community: Intangible Cultural Heritage and Educational and Participatory Practices in Istria) por evidenciar o trabalho que os museus podem desenvolver em torno da valorização e salvaguarda do Património Cultural Imaterial (PCI) em contexto local e com as comunidades, colocando em perspectiva alguns programas que o Istrian Ethnographic Museum's Centre for Intangible Culture (Pikán, na Croácia) vem desenvolvendo desde 2011. Mario Buletić (conservador do museu), entre os programas promovidos pelo museu, sublinhou o impacto de iniciativas como a realização de workshops informais direccionados a um público escolar e universitário. O que é realçado nestes workshops mediados pelo museu é a possibilidade que podem ter, como espaços informais complementares aos programas educativos formais, na desconstrução de uma noção de PCI, entendida, em muitos casos, pelas instituições como cultura tradicional estritamente ligada às zonas rurais e respectivas formas de vida (p. 82); e por outro lado, estimular uma reflexão crítica sobre o que é a cultura e o património de cada um e o respeito e tolerância pela cultura de "outros". Esta proposta apresenta-se num quadro diferenciado e, até certo ponto, de crítica aos mecanismos de inscrição de uma determinada prática cultural nas listas internacionais reconhecidas pela UNESCO cuja atracção neste país (e em muitos outros) tem suscitado grande interesse e agenciamento, sobretudo pelos actores ligados ao turismo e à política (p. 78). Enquanto alternativa às lógicas mainstream de salvaguarda do PCI ancoradas exclusivamente na inscrição de práticas culturais em listas "representativas", este capítulo evidencia o papel dos museus e as potencialidades de trabalhar com o PCI à escala local, apostando em projectos que primem pela inclusão, educação e participação, sublinhando ainda o papel dos mediadores, enquanto elementos-chave entre as populações, pela possibilidade de fortalecerem uma ponte entre as comunidades e os profissionais de museus na elaboração de projectos participativos.

o livro esclarece sobre tópicos que são hoje matéria de questionamento no mundo dos museus, revelando diferentes dinâmicas em curso. Por essa razão, esta colectânea pode ser de grande utilidade para os que têm particular interesse na museologia contemporânea, sejam estudantes, investigadores ou profissionais de museus. 


\section{BIBLIOGRAFIA}

Mairesse, François, ed. 2016. Nouvelles Tendances de la Muséologie. Paris: La Documentation française.

Mensch, Peter van, e Léontine Meijer-van Mensch. 2011. New Trends in Museology. Celje, Slovenia: Museum of Recent History Celje.

\section{NOTAS}

1. A autora escreve de acordo com a antiga ortografia.

\section{AUTORES}

\section{ANA CARVALHO}

Centro Interdisciplinar de História, Culturas e Sociedades (CIDEHUS) da Universidade de Évora, Portugal, arcarvalho@uevora.pt 